\title{
Dining with Philippe Lejeune: Just Desserts
}

\section{Clare Brant}

For the title of my tribute to Philippe Lejeune, I first considered this: 'une crème brûlée au vin jaune ... orgasmique!' Initially it seemed a bit risqué and possibly short of that decorum which Philippe always shows in person-so much so that, when I stay in the same hotel as him for a conference, I actively look forward to exchanging civilities with him. He has an impeccable way of saying Bonjour which makes me think wistfully of other eras, ones with better manners than scruffy modern Britons can muster. I had the nerve to tell him this, after which he indulged me by saying Bonjour to me far more often than was necessary, and with a twinkle. That combination of exactitude and understanding seems very Philippe-and perhaps very French. Certainly his intellectual virtues seem enviably French-I write as a Briton who remembers the so-called theory wars of the 1980 s, when parts of British universities were convulsed by hostility to Derrida, and anything French was divisive. As one intrigued by structure, sign and play, I sided with the moderns and side-stepped new historicism. But it felt as if something was missing: something human, yet not simply humanism. I found it in French writers-Barthes, Bachelard, Diolé-and in the writings of Philippe Lejeune. The autobiographical pact was so compelling as an idea I even tried reading it in French-though to say my French was un peu rouillé would be to imply it had had metal to rust, which is shamefully untrue. Hence I am immensely grateful to John Paul Eakin and Julie Rak for translating On Diary. What a task: Philippe is a lucid and yet inventive writer-again, perhaps in a French way, but it seems rare in literary criticism to be so clear, compelling and philosophically suggestive all at once.

I will come back to the crème brûlée. 
The autobiographical pact is a conceptual adventure, and a demonstration of something between ethics and manners: a gift of understanding what happens between writer and reader. Historians need at least to think about this in relation to the past: Philippe practised it in relation to a swiftly changing present. Those of us too old to be digital natives have had to adapt to a great deal of technological change which poses emotional challenges, as change does: do you hang on to old practices? Does nostalgia make you valorise the past? Are you tempted to dismiss the new because it is new and therefore often frightening? As Philippe began to read blogs and internet journals, he folded them into his critical practice with courtesy, openness and warmth. On a blog in 2000, for instance (On Diary, 316), he asks whether he would like this blog as much in book form, and then critiques himself: "the wrong question: why is the book the point of reference? For the past century it has kept diaries in shackles. Real diaries, infinitely and deliciously chatty, are condensed and cut down to fit these Procrustean beds, leading to tortured expectations about "style" and "depth." So far, so very readable: we are reminded of the special relationship between diaries and manuscript or, updated, of diary and file, and how their democratic freedoms call literary values into question. Then Philippe gives us an image of glorious liberty, of cultured relaxation: 'We taste them like liqueurs. On the Internet, the diary can finally breathe, stretch out on a chaise longue and relax.' And the critic can finally breathe: suddenly here am I the reader stretching out so effortlessly I am certain there is a cocktail to hand. 'Computer files and loose-leaf pages lend themselves wonderfully to writing fragments. But files are even better than notebooks for endless accumulation.' How free we are here! There is no rivalry between forms, no demands for particular shapes to forms; the collectors' drive and defence against death is understood and accepted. Rapprochement, bonhomie, accord: we are given a generous mood. 'And the website is a garden with pathways, crossroads, and viewpoints; it turns time into space without shrinking it.' It's like being in a painting-maybe Cézanne's L'Etang des Soeurs, or Renoir painting Monet painting his garden at Argenteuil. The solid proverbiality of procrustean beds is dissolved by the heady image of liqueurs. I can taste the black raspberry of Chambord. The chaise longue provides indoor velvet, leisurely comfort; the garden invites us to stroll, openminded. I don't want to leave. But the paragraph and the entry end: one must move on.

Let us move gradually towards the crème brûlée.

One of the conferences I attended was the first IABA Europe conference, in Amsterdam at the Vreije Universiteit. It has an excellent bookshop, in which I came across a mesmerising set of pre-designed 
diaries. They were a set, though possibly no one person would use them all because each was devoted to an interest. There was a wine-drinking diary, a gardening diary, a travel journal, a reading journal and a film diary, each colour coded. A quick online check supplies this trade description:

Centreing on the 6 big passions of the world (recipes, wine, music, books, wellness and film), Moleskine now offer this range of 6 notebooks specifically tailored to each passion. Wellness features 6 themed sections to be filled in, 6 blank sections to be personalised, food facts, conversions and measurements, blank pages and 202 adhesive labels [to] further personalise the notebook. Also features acid-free paper and an expandable double inner pocket.[https://wordery.com/moleskine-passion-wellness-journal]

Possibly to support this grandiose-and absurd-claim to define world passions, each also comes with a French title: Carnet Vins, Carnet Livres etc. There is also a Restaurant Journal, a diary of dining out experiences; a Beer Journal, and a Dessert Journal: Carnet Dessert.

When I first saw them I was so struck by their perfect manifestation of structuralism I sat up that night for hours writing a long analysis of them. My notes were later destroyed in a fire, but I didn't forget the journals. Had it not been for Philippe's work on diaries, I wouldn't have been nearly so interested, nor had as sharp tools to form a critical understanding of them. The encounter was an influence in my teaming up with Dr Polly North, Director of the Great Diary Archive, a repository for diaries held at Bishopsgate Institute in London. We curated an exhibition: Dear Diary: A Celebration of Diaries and their Digital Descendants, which ran 26 May-7 July 2017 at King's College London's Inigo Rooms at Somerset House. Some of our exhibition space metamorphosed from rooms to walls in the course of planning. Rather than curse the administrators who were responsible (though we did), we decided to use the walls for thought-provoking quotations. It was obvious we should choose some lines by Philippe. Reading criticism in order to lift a quotation is a rather specialist approach-a blank wall is curiously like and not like a blank page-but we were spoilt for choice. For example, these:

'Everyone has an opinion on the diary. No one feels unqualified. Everyone takes their little bit of experience as the norm. ...I first observed this in myself' (On Diary, 154).

'People pretend to be in dialogue. They think they are asking for feedback, but all they hear are echoes' (302).

'The most difficult part is imagining what the diary means to its author while he is keeping it and when he rereads it. Because a diary is like lacework, a net of tighter or looser links that contain more empty space than 
solid parts. Everything depends on what sea you throw it into. By the time it reaches us, it is nothing but a mass of strings lying on the beach at low tide' (153).

'Keeping a diary is a way of living before it is a way of writing' (153).

'There is no such thing as a typical diarist. ... there are as many diarists out there as stars in the night sky' (154-155).

We settled happily on that last one: aphorism and image, d'accord; it went above a vitrine of diarists of different eras all keeping household accounts. I liked the idea of numberless stars above numbers.

The exhibition had a response wall, a visitors' book and an attendants' diary (entries will be viewable on the Ego Media research group's website, http://www.ego-media.org/.) Singly, in clusters and en masse, the comments which our visitors volunteered vindicated Philippe's faith in the diary as a fascinatingly various and human genre. All sorts of people shared with us their day and their thoughts. 'People no longer have a confessor inside them, but a confidante' (On Diary, 335).

And this is true of Philippe himself. In an essay at the end of On Diary, he writes about his own diary. He began it on 11 October 1953, aged 15 . He tells us much about why and how, all interesting, but what stays with me more is the story which gives the essay its title: 'Lucullus Dines with Lucullus.' The story, from Plutarch, tells how Lucullus's steward set only a moderate table on a night his master was dining at home alone. Lucullus reproves him: 'What, did you not know, then, that to-day Lucullus dines with Lucullus?'

It is a wonderful story and it prompts Philippe to reflect, 'What is a personal diary? Is it when Lucullus dines with Lucullus, and there is just one dish on the menu-Lucullus himself?' He is too fine a writer to over-extend the metaphor: 'let's just use the notion of self-hospitality and the Lucullus story as hook, and then go on to reason freely' (330). How very Lejeune. It may be overextending etymology to point out a kinship between dining and jejune (my typing is as full of errors as my French) but there is one. The word to dine-and its French equivalent, dine-r-flower out of the late Latin disjunare, or dis-jejunium, to undo a fast, in English, as in breakfast, or break-fast; in modern French, as in lunch, de-jeuner. (What a world of cultural difference lies in that meal preference!) The pejorative jejune, which English takes simply from the French, comes from the Latin jejunus, fasting. In the seventeenth century it acquires a figurative meaning, devoid of nourishing qualities. Interesting shifts were taking place in the seventeenth-century food lexicon: in English there arose a lovely phrase, to dine with Duke Humphrey, meaning to go dinnerless. Its origin is unclear. Thinking 
about Lucullus again, what Philippe calls 'auto-hospitality' puts forward a brilliant model for relations with oneself-in diaries, but not just in diaries. Dignified, satisfying, cordial, it has transactionality, conversation, appetite, urbanity. We might also remember that before the digital era's ubiquitous company of phones, dining alone in a restaurant could require some courage.

We are almost ready for crème brûlée. It comes by way of two unexpected coincidences. One is how critics, myself included, reach for the word impeccable to describe Philippe. On the back cover of On Diary, Michael Riffaterre declares 'Lejeune's erudition and methodology are impeccable.' Etymological addiction means pointing out that impeccable comes from theology, without sin, secularised into faultless. In celebrating Philippe's contribution to scholarship, to the world of ideas and to humanity, especially diary-keeping, impeccable is high praise indeed. So to the next coincidence, which is that in Besançon in eastern France there is actually a Restaurant Lucullus. What erudite restauranteur named it, one wonders? Did it share the story of Lucullus with its customers? Like Philippe, it appears to have attracted many admirers and the highest praise: 'tout y est impeccable' says one satisfied diner, half identifiable as 'tiphai' on the website (https://www.yelp.com/biz/le-lucullus-besançon) Thanks to Philippe's impeccable criticism, one can understand this diner's review like a diary entry, or a mass of strings lying on the beach at low tide, from which one can, with difficulty, reconstitute some lacework. It must have been a delicious evening:

Une crème brûlée au vin jaune ... orgasmique !

Une de nos enseignes préférées avec mon amoureux, les poissons, les viandes, le foie gras, les st jacques, le vin, le service, les portions, le prix, tout y est impeccable. Le cadre est intime et classieux. Ne partez pas de ce restaurant sans avoir pris un dessert la crème brûlée est absolument orgasmique !

A créme brûlée with yellow wine ... orgasmic! [yellow wine is a speciality of the Jura region]

One of our favourite places with my lover, the fish, meats, foie gras, scallops, wine, service, portions and price, everything is impeccable. The setting is intimate and classy. Don't leave the restaurant without having had a dessert ... the crème brûlée is absolutely orgasmic!

The Restaurant Lucullus is no longer open. 


\section{ABOUT THE AUTHOR}

Clare Brant is Professor of Eighteenth-Century Literature \& Culture at King's College London, where she co-directs the Centre for Life-Writing Research with Max Saunders; they are also the General Editors of the Palgrave series Studies in Life Writing. Her most recent publication is Balloon Madness: Flights of Imagination in Britain 1783-1786 (Boydell \& Brewer 2017); she was also the co-curator of an exhibition in London in 2017, Dear Diary: A Celebration of Diaries and their Digital Descendants. 